\title{
Turkey as a Special and (Almost) Dead Case of EU Enlargement Policy
}

\author{
Barbara Lippert
}

\subsection{INTRODUCTION}

Turkey has always been a special as well as difficult case in the context of European Union (EU) enlargement. Early on, Ankara's drive toward Brussels posed many fundamental questions for the European Communities (Lippert, 2005a). Thus, Turkey's plea for membership, with a formal application sent to Brussels in 1987, contributed to the general development of association and enlargement policies by the EU and to the interplay between them. The political and economic criteria for membership, interests in enlargement among elites in member states and third countries, and the role of public opinion all had to be considered. The ups and downs in the decades-long relations between Brussels and Ankara in the context of enlargement indicate the difficulties both sides experienced in terms of commencing and concluding accession negotiations. Today, the outcome is highly uncertain. The EU and its members have somewhat lost their sense of purpose and strayed from their earlier strategy on

B. Lippert $(\bowtie)$

German Institute for International and Security Affairs / Stiftung Wissenschaft und Politik (SWP), Berlin, Germany

e-mail: barbara.lippert@swp-berlin.org

(C) The Author(s) 2021

W. Reiners and E. Turhan (eds.), EU-Turkey Relations, https://doi.org/10.1007/978-3-030-70890-0_11 
bilateral relations. It is questionable whether Turkey even is still a case for enlargement or whether it has already turned into a dead case.

To describe and explain Turkey as a special case of EU enlargement policy, this chapter focuses on the following aspects. Firstly, the overall concepts, motives, and criteria of EU enlargement are introduced. The second section deals with critical questions that Turkey poses for the EU in this respect, in particular in view of Turkey's 'Europeanness', its strategic value, political order, democracy, and political culture, and in terms of the EU's capacity to absorb a new state. The third section outlines how pre-stages of the accession process, negotiation framework, and the conduct of negotiations have played out. The focus is thus on issues that make Turkey a special and (almost) dead case of EU enlargement policy. The chapter concludes with a brief outlook on future bilateral relations.

The bulk of recent contributions to the study of EU-Turkey relations is notably from think tanks that monitor the increasingly strained relationship and develop policy proposals for how to overcome the deadlock (e.g., Dalay, 2018; Carnegie Europe, 2018; Hoffman \& Werz, 2019; Pierini, 2019). As far as earlier academic contributions are concerned, EU-Turkey relations were largely considered in terms of the analytical concepts of Europeanization, transformation, modernization, and external governance. These topics were therefore analyzed in the literature on enlargement and accession policy or neighborhood policy, even if this did not coincide with the EU's geographic definition of European Neighborhood Policy (e.g., chapters on 'Turkey and enlargement' in Weidenfeld \& Wessels, 2005-2019; chapters on 'Wider Europe' in Copsey and Haughton, 2012-2014; Fraser, 2004; Rehn, 2006; Seufert \& Fischer, 2018; Dürkop, 2018; Leiße \& Tryk, 2004; Schimmelfennig, 2018; Tocci, 2014). With the diminishing role of the enlargement framework and tensions over Turkey's membership of the North Atlantic Treaty Organization (NATO), research on EU-Turkey relations is likely no longer to be conducted primarily through the lenses of accession and enlargement, ${ }^{1}$ analyzing domestic developments inside Turkey and Ankara's foreign relations, but increasingly shift back to classical concepts

\footnotetext{
${ }^{1}$ See, for example, the research program of the Center for Applied Turkey Studies (CATS), established in 2019 in Berlin, https://www.swp-berlin.org/en/cats-turkey/. See also Turhan and Reiners, Chapter 1.
} 
of International Relations (e.g., structural realism) or comparative government (e.g., hybrid regimes, authoritarianism, etc.) (e.g., Özerdem \& Whiting, 2019; Talbot, 2018; Goff-Taylor, 2017; Morillas et al., 2018; White \& Herzog, 2018).

\subsection{CONCEPT, Motives, ANd Criteria of EU ENLARgEMENT}

Enlargement is about extending the geographic scope of the legal and political acquis to third countries that join the EU. Thus, enlargement policy is not a clearly defined policy field (as are, for instance, competition policy or foreign and security policy) but a horizontal approach that impacts the EU's polity, politics, and policies. It concerns fundamental principles and provokes soul-searching exercises at the EU and national levels about the EU's political identity and its wider aspirations. At the same time, it tests existing policies and compromises over the distribution of power and resources within the EU and thus affects the internal equilibrium in many ways (Lippert, 2011: 238-239; 2019a: 23-25).

In practical terms, enlargement policy is defined as the accession of new members to the EU, including the EU's strategies, activities, and procedures related to this process. Over successive rounds of enlargement, the EU modified its enlargement policy in response to the specific demands of new entrants. In this context, it developed an ever more comprehensive pre-accession strategy. The EU also takes account of its own absorption capacities in light of the state and dynamics of European integration. The drivers of enlargement are mainly European third countries, such as Turkey, that want to join the EU. They expect EU membership to serve their security interests, to improve their prosperity, and to anchor or advance their democratic political order (Lippert, 2011: 243-244). The EU's motives for enlargement are generally not as explicit and straightforward as they are for candidate countries. Generally speaking, the EU is eager to frame accession as a win-win opportunity. There are also endogenous factors that drive enlargement from inside the EU. Right from the start all European Communities defined and understood themselves as communities open to new members. ${ }^{2}$

2 'Any European State may apply to become a member of the Community. It shall address its application to the Council which, after obtaining the opinion of the Commission, shall act by means of a unanimous vote' (Art. 237 EEC Treaty). 
The EU does not choose or ask countries to join; it merely examines the applications of those European countries that want to join. It does, therefore, need membership criteria. While the democratic credentials of the first applicant countries, Denmark and the United Kingdom (UK) in 1961, were seen as unproblematic, others were not. On the occasion of the application of Spain under Franco for association in 1962 (Powell, 2015: 7) and the association negotiations with Greece and Turkey in the early 1960s, the European Economic Community (EEC) started to develop criteria and procedures to formalize relations with third countries. In the case of both association and accession, the European Commission (EC) and the European Parliament (EP) realized that the political terms of the future relationship were critical and deserved special attention. As such, a member of the European Assembly, Willi Birkelbach, produced a report that outlined both the political and the economic criteria for future members (Birkelbach, 1962: 5; see also Lippert, 2011: 250).

This acted as a precursor to the Copenhagen criteria, defined by the European Council in Copenhagen in 1993. The Copenhagen political criteria stipulate that 'membership requires that the candidate country has achieved stability of institutions guaranteeing democracy, the rule of law, human rights and respect for and protection of minorities' (European Council, 1993: 13). This set of political criteria was not directly copied into the written provisions of the treaties, but its substance is referenced in the values of the EU as laid down in Article 2 of the Treaty on European Union (TEU). Article 49 of the TEU, and political documents produced in the course of developing the practical enlargement policy mostly by the European Council and the Commission, define core elements with regard to the political compatibility of applicants: 'Any European state which respects the values referred to in Article 2 and is committed to promoting them may apply to become member of the Union'. Moreover, the European Council has the right to define conditions for membership, as it had already done with the declaration of the Copenhagen criteria in 1993 (see Turhan \& Wessels, Chapter 8). Beyond the political criteria, the Copenhagen criteria included the economic criteria and the so-called acquis criteria:

[...] the existence of a functioning market economy as well as the capacity to cope with competitive pressure and market forces within the Union. Membership presupposes the candidate's ability to take on the obligations of membership including adherence to the aims of political, economic and monetary union. (European Council, 1993: 13) 
Based on these criteria, the EU applies a policy of conditionality (Börzel et al., 2017; Schimmelfennig, 2008), understood as the expectation that once the applicant has fulfilled all conditions, the country can join the EU. The Commission was tasked with closely monitoring progress in candidate countries toward this goal. To support candidates' efforts in the pre-accession period, the EU committed itself to the transfer of money under the Instrument for Pre-Accession Assistance, know-how (for institution building, setting up of public administration), and participation in community programs (see also Bürgin, Chapter 9).

\subsection{Critical Questions for the EU With Regard to Turkey's Membership Application}

\subsubsection{Europeanness}

Following Turkey's official application for membership in 1987, the first question to be answered was whether or not the EEC regarded Turkey as a European country. 'Europeanness', although at no point defined in the European treaties, has always been the principal condition to qualify as an applicant. Famously, in 1987 the Commission immediately turned down Morocco's application because it did not count as a European country. In contrast, the path toward accepting Ankara's application was already paved in the 1960/1970s when the EEC consistently agreed that Turkey qualified as European. At that time a purely political, not a geographic, historical, or cultural definition, prevailed among member states. From their view Turkey was firmly placed in the West: Ankara was a Marshall Plan beneficiary and later on a member of the Organisation for Economic Co-operation and Development (1961), the Council of Europe (1950), and NATO (1952). In the Cold War era, the first president of the Commission of the EEC, Walter Hallstein, stated that the EEC and member states shared Turkey's aspiration for membership (Kramer \& Reinkowski, 2008: 156). A case in point is Article 28 of the Association Agreement of 1963, which concluded that the EEC will later consider membership for Turkey (EEC-Turkey Association Agreement, 1963: Art. 28). Thus, the initial agreement among the six EEC members that Turkey was a European country that could apply for membership created path dependency from the early 1960s until today. EU institutions never officially retreated from this early stance. However, when the EEC reacted to Turkey's first official application, some governments and public 
opinion in EEC member states challenged Turkey's 'Europeanness', based on the changing geopolitical landscapes after 1989 (see below). Thus, the EU's clarity in regard to Turkey's Europeanness, and the credibility of Turkey's prospective membership were stronger on paper than in reality even in the late 1980s.

\subsubsection{Strategic Value}

Turkey's strategic value for the EEC has always been its geographic location. After the Second World War, Turkey secured the southeastern flank of NATO in its posture against the Soviet Union. Throughout the Cold War and beyond Turkey's prospective membership was also regarded as a means to soften tensions between Turkey and Greece, which had already become a member of the European Communities in 1981. It was also hoped that Turkey's membership would contribute to the resolution of the Cyprus conflict. Perceptions in the EU changed in the aftermath of 1989.

As a player in East-West politics and as a cornerstone of a post-Cold War European security architecture, Turkey's membership was given less importance in the 1990s, when the Central and Eastern European countries (CEECs) were first in line for membership negotiations (Seufert \& Fischer, 2018: 274). Turkey was neither included in the so-called Luxembourg group in 1997, nor the Helsinki group that received roadmaps and indicative dates for the opening of negotiations. At the Helsinki Summit in 1999 EU leaders did grant Turkey candidate status so that it became part of the pre-accession process (European Council, 1999), but there was no clear indication of when negotiations would start. The EU took this decision in the context of the Kosovo war and the destabilization of the Balkan region. The security argument in favor of Turkey's membership had become increasingly contested because of Turkey's ambivalent role in its neighborhood as well as the Kurdish question inside Turkey and beyond its borders (Seufert, 2018a). Since the US war in Iraq in 2003, many EU actors have considered Turkey as part of the unstable Levantine region in the Middle East. In terms of stability, Turkey's membership could be seen as either an asset or a liability to the EU (Barkey \& Le Gloannec, 2005; Lippert, 2005a).

From the start of the Arab Spring of 2011 and the ensuing war in Syria that triggered the destruction of the regional order in the region, Turkey's strategic importance for Europe and the EU increased but at the same 
time became more complex and strained (Morillas et al., 2018). From the mid-2000s onward, Turkey's foreign policy under Foreign Minister Ahmet Davutoğlu proactively pursued a policy of 'strategic depth' (see Torun, Chapter 13). Distancing itself from the West without giving up its membership aspirations Turkey sought - unsuccessfully-a more diversified policy and declared a policy of 'zero problems with neighbors' that was sometimes at odds with EU positions (Michel \& Seufert, 2016: 86). The EU was confronted with a Turkey that played an opaque role as a provider of both order and disorder in the region (Karadag, 2017: 42-46).

Turkey's overriding strategic importance for the EU was again highlighted in summer 2015 at the peak of the inflow of refugees to the EU from war-torn Syria. Since then, Turkey's relations with the EU and also the USA and NATO have further deteriorated. Turkey has turned from an ally to an unreliable partner of the West that has leaned toward Russia and Iran. The EU realized that Turkey did not align with the EU's positions taken in the Common Foreign and Security Policy framework (Council of the EU, 2019a: para. 36). However, while criticizing Turkey's democratic backsliding, the EU still acknowledged Turkey as a 'key partner/country' and 'strategic partner' (Council of the EU, 2019a: para. 30; 2019b). The EU-Turkey Statement on irregular migration in March 2016 (the refugee 'deal') was an example of Realpolitik and showed the new balance of power between both parties (European Council, 2016). Even then, the EU could not escape the nexus with the negotiation framework-a sentence on the opening of new chapters was inserted in the declaration despite a lack of progress in Turkey to meet the political criteria.

\subsubsection{Political Order, Democracy, and Political Culture}

Despite Turkey being part of the Western bloc for geostrategic reasons, its internal political development nurtured constant doubts as to its political credentials as a Western democracy. Attempted or executed military coups and interventions (1960, 1971, 1980-1983, 1997, 2016), disregard for separation of powers, rule of law, and human rights (including the Kurdish question) as well as the lack of political pluralism provided no firm basis for the opening and continuation of membership negotiations. Contrary to more linear transitions from dictatorship to democracy in Spain, Portugal, and Greece in the 1970s, Turkey's democratization and modernization were often set (or rolled) back, be it for structural or 
specific reasons. Thus, the wave of democratization in the 1970s passed by Turkey (Leggewie, 2004: 12) gained (only temporary) ground as late as 2002 with the change of government to the Justice and Development Party (Adalet ve Kalkınma Partisi, AKP), which had a conservative and religious platform.

Turkey used the accession process under former Prime Minister and current President Recep Tayyip Erdoğan as a favorable framework for reducing the power of the secular political camp of the Kemalists and for abolishing the military's stronghold. The accession process helped strengthen the economic and social advancement of Turkey's religioustraditional-conservative groups, which supported the AKP (Dağ1, 2006; Seufert, 2018b: 13-16). The EU initially welcomed the liberalization steps and supported the economic upswing in Turkey that went along with this. The EU and the Turkish government opened accession negotiations in 2005 based on the assumption of continuing domestic political transformation. However, since the Gezi park protests in 2013 the AKP government has not been following a consistent course of Europeanization $^{3}$ but rather has been working toward converting the political system to authoritarian presidential rule. Since the state of emergency following the thwarted coup d'état in 2016, Turkey has drifted so far from meeting the political criteria of membership that a formal halt to negotiations was demanded by the EP and several national governments. Sebastian Kurz, then foreign minister of Austria, for instance, demanded the EU freeze accession negotiations in a December 2016 meeting of the Council of the EU (Gavenda, 2017).

The AKP's turning away from secular Kemalism, and the Islamization of Turkey, have strengthened the perception of Turkey-skeptic segments of the EU population. In the EU, the debate resurfaced over whether Turkey is different because of its history, culture, and Muslim character. In light of the Copenhagen criteria, the EU has implicitly regarded these debates as subjective and guided by identity politics in an attempt to fixate on 'cultural difference' (see Leggewie, 2004; Seufert \& Kubaseck, 2006; Kramer \& Reinkowski, 2008: 177-180). The EU started the

\footnotetext{
${ }^{3}$ Europeanization refers to the shift of attention of institutions, actors, notably policymakers at the national level to the EU-level as well as their gradual participation in EU-policymaking and decision-making processes. The term also refers to respective modes of governance and norms transfer of actors on the EU-level top down to the national level (see Radaelli, 2003; see also Alpan, Chapter 5).
} 
accession process from the working hypothesis that Islam as a religion and cultural community is in principle compatible with the political criteria of membership and, as such, is irrelevant to the EU's monitoring processes. Thus, the Commission applied its standard checklist of political criteria-as documented in the annual regular reports-throughout the pre-negotiation and negotiation period in order to measure their fulfillment (see, e.g., European Commission, 2019: 9-40). Starting from the government's reaction to the Gezi park protests in 2013, Turkey's record on all key criteria items, such as fundamental rights, and the independence and functioning of the judiciary became increasingly negative. In 2019 the Council was ' $[\ldots]$ especially concerned about the continuing and deeply worrying backsliding on the rule of law and on fundamental rights' (Council of the EU, 2018: para. 31).

Concerns relating to Turkey's political culture are discussed in member states and across parties, media, and the wider public. Indeed, Turkey's candidacy has become one of the more prominent issues in the public eye (Özbey et al., 2019). According to a YouGov survey in 2016, there is distinct hostility to Turkey joining the EU. In Germany (86\%), Finland $(83 \%)$, Denmark $(82 \%)$, France $(74 \%)$, Sweden $(73 \%)$, and even in the United Kingdom (67\%), there are large majorities against Turkey's accession to the EU. In these countries, even Russia would be more welcome in the EU than Turkey (YouGov, 2016).

\subsubsection{Impact and Absorption Capacity}

Opposition to Turkey's membership has often been summarized by the verdict that Turkey is 'too big, too poor, with too dangerous borders and insufficiently 'European' to join the Union'. (Hughes, 2004). Indeed, Turkey's size matters, as Turkey would be the biggest member ever in terms of territory and population, ${ }^{4}$ giving it strong voting power in the EU's decision- and policymaking system. Although Turkey has caught up economically over the years, it is a country with huge regional disparities and relatively low per capita levels of income. In 2017, its gross domestic product (GDP) per capita was 66\% that of the EU28 average (European Commission, 2019: 107). Additionally, the weakening of the Turkish economy since 2018, especially Turkey's high current account

\footnotetext{
${ }^{4}$ Population of 79.8 million and area of $780,270 \mathrm{~km}^{2}$ in 2017 , which is almost $1 / 5$ of the total area of the EU27 (European Commission, 2019: 107).
} 
deficit, has led to deep concerns over the functioning of the country's market economy (European Commission, 2019: 52). Therefore, the debate about overstretching the Union and the limits of its capacity to absorb additional countries has been applied to Turkey more often than, for example, to the CEECs and Balkan countries.

This debate refers to considerations that the EU makes in the Copenhagen criteria, stipulating, as a 'fourth criterion', that

[t]he Union's capacity to absorb new members, while maintaining the momentum of European integration, is also an important consideration in the general interest of both the Union and the candidate countries. (European Council, 1993: 13)

EU institutions and leaders have frequently insisted on the importance of taking the 'absorption capacity' of the Union into account after the big bang enlargement (see for example Council of the EU, 2006a: 1). Turkey and other applicants, on the other hand, have criticized the EU for being absorbed with internal reform blockages or other challenges, as in the decade of the 'polycrisis' (Juncker, 2016) from 2008 onward, to the detriment of the applicants.

On all items discussed here-Turkey's 'Europeanness', its strategic value, its democratic credentials, and its impact on the EU as a membera degree of doubt and uncertainty remained among member states as to whether Turkey would fit as a member. These doubts and ambivalences were partly tamed and pragmatically channeled through the political rules and bureaucratic policy that the EU has set up to conduct the negotiation processes.

\subsection{Enlargement Doctrine and Management of Turkey's Accession Process}

With the advent of the first round of enlargement in 1973, the EEC developed core elements to its enlargement doctrine to ensure the smooth integration of new members (Lippert, 2011: 248-258). The first core element, already discussed above, is that a new member must fulfill all political criteria. A second element is that the EU's acquis communautaire et politique is not negotiable. Any new entrant has to accept and implement all primary and secondary laws in full. This makes the relationship, per se, asymmetric and secures EU dominance throughout the 
pre-negotiation and negotiation period. The third element is the absorption capacity of the EU, as explained above. All three elements were taken up in the so-called renewed consensus on enlargement (European Council, 2007: 2). While the management of Turkey's application by and large fits into the EU's general enlargement approach, some features stand out, which will be discussed in the following sections.

\subsubsection{Pre-stages: Association, Customs Union, Application for Membership and Candidate Status}

Turkey (and Greece) set the example of what has become the typical staged process from free trade and association to the application for membership. However, the reference to future membership in Ankara's Association Agreement (Article 28) is a provision not found in other cases, aside from that of Greece. The EU, thereafter, thought that a political commitment of this kind was both too strong and binding (as for the CEECs in the 1990s or today for Ukraine or Georgia) or not necessary (Norway). Due to the lack of experience with association agreements at the time, internal EU conflicts over competencies and political uncertainty following the military coup in Turkey in 1960, the Association Agreement was only signed in 1963 after four years of negotiation (Ceylanoğlu, 2004: 152-154; see also Turhan \& Reiners, Chapter 1). As a compromise between a customs union (CU) (favored by the Commission and Germany) and a mere cooperation agreement (favored by France and Italy) (Ceylanoğlu, 2004: 254), the Association Agreement stipulated that a CU was to be established over a transition period of 12 years and after a preparatory phase of at least five years. Only after the preparatory phase would the details of the transition period be decided on with unanimity. These stipulations reassured the skeptics within the EU that any future developments could still be stopped (see Kramer \& Reinkowski, 2008: 157-158).

In 1987, Ankara applied to join the EU (then EEC). Although not formally rejected, the Commission stalled Turkey's membership application in 1989, referring to a number of reasons on both sides: the limited institutional absorption capacity of the EU after the Southern enlargement (1987) and in light of the coming European Free Trade Association enlargement (1995), the priority of the internal market project (1992), the forthcoming eastern enlargement, Turkey's unresolved conflict with Cyprus, and the notorious democratic deficits in Turkey (European 
Commission, 1989: 7). Thus, the establishment of the CU with Turkey as an intermediary step, and as some sort of compensation for the preaccession processes with the CEECs, gained support inside the EU as the first or second-best choice in lieu of membership. To structure the lengthy accession processes the EU introduced the status of 'candidate', which has become a necessary stepping-stone to opening negotiations. In the aftermath of the December 1997 Luxembourg European Council that turned down candidate status for Turkey, Ankara declined the EU's offer to take part in the so-called Europe Conference (until 2000), which the EU had first organized in 1997 as a pan-European format to compensate potential applicants for which there was as yet no prospect of accession negotiations being opened (Lippert, 1999: 46; 2000: 41).

The decision on Turkey's candidate status, agreed in December 1999 at the Helsinki Summit (European Council, 1999), was initially contested among member states. A breakthrough came with a favorable alignment of the stars in important EU-member states: support from Germany under the newly elected red-green government (Gerhard Schröder/Joschka Fischer), from France under President Jacques Chirac, and Greece under Prime Minister Kostas Karamanlis. The turn toward enlargement as a foreign and security policy instrument against the background of the Kosovo war also benefited Turkey's candidacy. During the Helsinki European Council meeting, Commissioner Günter Verheugen and the High Representative Javier Solana traveled to Ankara to explain to the still reform-reluctant Ecevit government that no further formal requirements other than the Copenhagen criteria would be applied to Turkey's candidacy. However, the EU had established a link between Turkey's accession process and the resolution of the conflict over Cyprus in the European Council conclusions (European Council, 1999; Kramer \& Reinkowski, 2008: 165-166). The Cyprus conflict hampered and still blocks the negotiation process. At several points it played into EU-Turkey negotiations, as did other bilateral conflicts in other cases (Dokos et al., 2018: 28-31; Hillion, 2010).

The decision to start accession negotiations with Turkey was gradual precisely because it was controversial. In 2002, the European Council agreed on a rendezvous clause. This clause stated that the EU would decide on the opening of negotiations with Turkey in 2004, provided that Turkey fulfilled the political Copenhagen criteria. When the EU25 finally decided in December 2004 to start negotiations with Turkey in October 2005, it was clear that some member states, namely Germany, 
Austria, and the Netherlands remained skeptical, and the EU therefore remained ambivalent as to whether Turkey would fit, in principle, and in terms of the concrete deficiencies of Turkey's democracy.

An immediate concern ahead of the December 2004 European Council was the unresolved bilateral conflict with Greece and the new EU-member Cyprus (see Lippert, 2005b: 429-431). In April 2004, the resolution of the Cypriot issue according to the 'Annan plan' failed to gain support of the majority in Greek-Cyprus in an island-wide referendum. To avoid a Greek veto on the upcoming Eastern enlargement, the EU had already promised Cyprus that it would become a member state of the EU, representing the whole island but without the acquis communautaire being implemented in the Cypriot-Turkish part of the country (European Council, 1999; see also Kramer \& Reinkowski, 2008: 165-166). Practical problems occurred in applying present and future rules for trade between the whole of the island and the EU (see for example, Council of the EU, 2006b). The EU insisted on Ankara signing the Additional Protocol to be annexed to the EEC-Turkey Association Agreement and Turkey's extension of the CU to the EU25-in other words including Cyprus. The EU was ready to take the implementation of the Protocol as a substitute for a formal recognition of Cyprus by Turkey and, at the same time, link the question of recognition to the accession process (Council of the EU, 2005).

\subsubsection{Framework for Negotiations}

Turkey was the only case in which EU institutions started talks with a country that only 'sufficiently' (European Council, 2004: 6) fulfilled the political criteria. The EU knew that Turkey's political problems were structural and severe. However, the EU was confident that the opening of accession negotiations would support political democratization and economic transformation in Turkey. Against this background, the EU sought many special arrangements in the negotiation framework, which would also be applied to another candidate, Croatia (Lippert, 2006: 433434). These arrangements were adopted by the European Council in December 2004 and included long or probably even permanent safeguard clauses (with regard to freedom of movement, structural policies, and agriculture), special regulations, and a suspension procedure. They were also integrated into the Negotiating Framework document prepared 
by the Commission that outlined the guiding principles of the negotiations with Turkey (European Commission, 2005). As provided for in this framework, the negotiations were designed to be open-ended, long-lasting, and not only dependent on Turkey's fulfillment of the Copenhagen criteria but also on the institutional absorption capacity of the Union (European Commission, 2005: para. 3). That way, even if Turkey complied with the acquis, the outcome of the negotiation process could not be guaranteed and EU membership would not automatically be granted.

In terms of procedure, a screening process ${ }^{5}$ was introduced, and it was decided to monitor progress through regular country reports on Turkey. At the same time, in the negotiating framework, the EU had already safeguarded against the possible failure of the negotiations, including a suspension procedure in case Turkey violated the fundamental political criteria. An alternative to membership was also considered

[i]f Turkey is not in a position to assume in full all the obligations of membership it must be ensured that Turkey is fully anchored in the European structures through the strongest possible bond. (European Commission, 2005: para. 2)

This could be interpreted not only as a fallback option but also as a hidden strategy, because some member states favored a so-called 'privileged partnership' or other forms of integration and cooperation with Turkey as a third country, not as a member of the Union (see Tekin, Chapter 7).

While the special provisions in the framework for negotiations could be seen as a means to deal with the challenges of integrating a special candidate (in terms of size, economy, and culture) and to reassure skeptical member states that the process could still be stopped, some authors argue that the negotiations were doomed to fail right from the start as the EU did not (sufficiently) encourage Turkey's political reform process in light of this fallback option (İçener et al., 2010: 215; Tekin, 2017: 39).

${ }^{5}$ During the screening process, the Commission presents the acquis of primary and secondary law for every negotiation chapter, then both sets of legal provisons are systematically compared. The (gradual) implementation of the EU's legal acquis is monitored in relation to fulfilling benchmarks defined by the Council in order that a decision can be made by the EU as to whether to open or close individual negotiation chapters. 


\subsubsection{Conduct of Negotiations}

In line with the general conduct of negotiations on membership, the European Council and the Commission have played a pivotal role in accession negotiations with Turkey. The European Council made all of the EU's strategic decisions on Turkey's accession milestones: the opening and the framework for negotiations, the introduction of new instruments and formats such as the Positive Agenda, and high level dialogues (see Turhan \& Wessels, Chapter 8). The Council machinery in Brussels, Coreper II, has been important for the preparation of decisions and the search for consensus among the governments prior to the General Affairs Council and/or the European Council coming into play. The EC has also been the manager of negotiations and pre-accession activities (see Bürgin, Chapter 9). In the case of Turkey, communication between the EU and Turkey has been intense even when the negotiations were slow or stalled. As in other cases, the European Parliament gave special attention to political developments in Turkey and more directly criticized Turkey's backsliding. The EP was at times split over whether the EU should explore alternatives such as that of 'privileged partnership'. It also called for a suspension of negotiations in 2017 and 2019 (European Parliament, 2017, 2019; see also Lippert, 2017: 423; Kaeding \& Schenuit, Chapter 10).

Compared to all other accession processes, the length of Turkey's negotiations is noteworthy. The main reason for this is the ambivalent position inside the EU toward Turkey's candidacy and future membership due to Turkey's insufficient fulfillment of political criteria and its own genuinely inconsistent accession strategy. Since October 2005, little progress has been made: only 16 of the 35 chapters have been opened, one of these is provisionally closed (see Table 11.1).

Since December 2006, the Council has suspended eight trade-related chapters ${ }^{6}$ as a response to Ankara's resistance to implementing the obligations stemming from the Additional Protocol, and no further chapters are to be closed until the resolution of the conflict with Cyprus (Council of the EU, 2006b). In relation to the remaining chapters, either Turkey does not meet the benchmarks, or their opening has been vetoed by single member states in the Council, including France (in 2007) and Cyprus (in

\footnotetext{
${ }^{6}$ The eight negotiation chapters related to trade-chapters $1,3,9,11,13,14,29$, and 30 - have therefore remained closed until today.
} 
Table 11.1 Status of negotiation chapters with Turkey (2020)

\begin{tabular}{|c|c|c|}
\hline Chapter & Opening & Provisional closure \\
\hline 1 Free Movement of Goods & Suspended & \\
\hline 2 Freedom of Movement of Workers & Vetoed & \\
\hline $\begin{array}{l}3 \text { Right of Establishment and Freedom to Provide } \\
\text { Services }\end{array}$ & Suspended & \\
\hline 4 Free Movement of Capital & 2008 & \\
\hline \multicolumn{3}{|l|}{5 Public Procurement } \\
\hline 6 Company Law & 2008 & \\
\hline 7 Intellectual Property Rights & 2008 & \\
\hline \multicolumn{3}{|l|}{8 Competition Policy } \\
\hline 9 Financial Services & Suspended & \\
\hline 10 Information Society and Media & 2008 & \\
\hline 11 Agriculture and Rural Development & Suspended & \\
\hline 12 Food Safety, Veterinary and Phytosanitary Policy & 2010 & \\
\hline 13 Fisheries & Suspended & \\
\hline 14 Transport Policy & Suspended & \\
\hline 15 Energy & Vetoed & \\
\hline 16 Taxation & 2009 & \\
\hline 17 Economic and Monetary Policy & 2015 & \\
\hline 18 Statistics & 2007 & \\
\hline \multicolumn{3}{|l|}{19 Social Policy and Employment } \\
\hline 20 Enterprise and Industrial Policy & 2007 & \\
\hline 21 Trans-European Networks & 2007 & \\
\hline $\begin{array}{l}22 \text { Regional Policy and Coordination of Structural } \\
\text { Instruments }\end{array}$ & 2013 & \\
\hline 23 Judiciary and Fundamental Rights & Vetoed & \\
\hline 24 Justice, Freedom and Security & Vetoed & \\
\hline 25 Science and Research & 2006 & 2006 \\
\hline 26 Education and Culture & Vetoed & \\
\hline 27 Environment & 2009 & \\
\hline 28 Consumer and Health Protection & 2007 & \\
\hline 29 Customs Union & Suspended & \\
\hline 30 External Relations & Suspended & \\
\hline 31 Foreign, Security and Defense Policy & Vetoed & \\
\hline 32 Financial control & 2007 & \\
\hline 33 Financial and budgetary provisions & 2016 & \\
\hline 34 Institutions & Vetoed & \\
\hline 35 Other issues & & \\
\hline
\end{tabular}

Source Own compilation based on Delegation of the European Union to Turkey (2020) 
2009). Thus, negotiations quickly entered a period of stagnation, and the Cyprus issue has become an obstacle, which has pleased those who wanted to slow down Turkey's accession, be it in Turkey or the EU. Given the EU's reluctance to smooth tensions on the island and to ease the isolation of Northern Cyprus, in 2011 then Prime Minister Erdoğan even challenged the EU by stating that his government would freeze membership negotiations (Seufert, 2011: 521-522). Turkey's new assertiveness was a signal to Brussels; its foreign policy was working toward a more symmetric, bilateral relationship, and a diversification of foreign policy partnerships (Seufert, 2018b: 16-18). At the same time, the course of domestic reform was slowing down considerably in Turkey. Hence, as a prospective future member state Turkey has become an increasingly more difficult case for the EU.

Annually, the Commission has taken stock of Turkey's domestic political developments in relation to it fulfilling the Copenhagen political criteria. Between 2005 and 2012, the Commission recorded both ups and downs as far as fundamental rights and the independence of the judiciary was concerned. Based on the Commission reports, the Council and the European Council frequently demanded additional reform efforts from Turkey, especially in the areas of freedom of expression, freedom of media, freedom of religion, property rights, trade unions, minority rights, control over military power, women's and children's rights, nondiscrimination, and gender equality. Since 2017, the Commission has abstained from commenting on whether or not Turkey 'sufficiently' fulfills the political criteria, which was the basis on which it gave the green light to the opening of negotiations.

Despite the special provisions in the negotiation framework and internal divisions, the Commission applied the Copenhagen criteria as well as the standard screening process and benchmarking to Turkey with the same pragmatism as was applied to the Eastern enlargement. Since the Barroso Commission, the accession negotiations have focused on the issues of rule of law, economic governance, and administrative reforms as primary conditions for membership (Council of the EU, 2014: para. 3; see also Lippert, 2015: 523). Given the veto deployed by Cyprus, the EU could not apply what had become its new standard approach: opening Chapters 23 and 24 related to judiciary, fundamental rights, justice, freedom, and security at an early stage in order to put additional pressure (and give additional support) on a country to comply with membership conditions in the sensitive areas of rule of law and 
fundamental rights. At the same time, in its progress reports on Turkey the Commission has paid special attention to these essential chapters and issues (see Table 11.2).

The attempt to revive the reform process with various initiatives and mechanisms, including the 2012 Positive Agenda, discussions on a modernization of the CU, and the 2013 roadmap for visa liberalization, has so far had little effect. Since two negotiation chapters previously vetoed by France (Chapters 17 and 33) were opened in the context of the refugee 'deal' in 2015 and 2016 (European Council, 2015, 2016), there has not been any progress. Although the EP demanded the suspension of the negotiations (European Parliament, 2017, 2019) the Council did not follow this request in 2017 and 2019 although it concluded that negotiations had 'effectively come to a standstill'; and that 'no further chapters can be considered for opening or closing' (Council of the EU, 2018: para. 37). Other dialogue formats, most of which were launched during the refugee crisis, continued for some time without significant effects on the accession process (Lippert, 2018: 523). In response to Turkey's drilling activities in the Eastern Mediterranean the EU even suspended meetings

Table 11.2 Progress and preparations for Turkey's EU membership (20182019)

\begin{tabular}{|c|c|c|c|c|}
\hline \multirow{2}{*}{ Area of Reform } & \multicolumn{2}{|l|}{ Progress } & \multicolumn{2}{|l|}{ Preparations } \\
\hline & 2018 & 2019 & 2018 & 2019 \\
\hline $\begin{array}{l}\text { Public } \\
\text { Administration } \\
\text { Reform }\end{array}$ & $\begin{array}{l}\text { Serious } \\
\text { backsliding }\end{array}$ & $\begin{array}{l}\text { Serious } \\
\text { backsliding }\end{array}$ & Moderately & Moderately \\
\hline Judicial System & $\begin{array}{l}\text { Serious } \\
\text { backsliding }\end{array}$ & $\begin{array}{l}\text { Serious } \\
\text { backsliding }\end{array}$ & Early stage & Early stage \\
\hline Corruption & No & Backsliding & Some & Early stage \\
\hline Organized Crime & Some & Limited & Some & Some \\
\hline $\begin{array}{l}\text { Freedom of } \\
\text { Expression }\end{array}$ & $\begin{array}{l}\text { Serious } \\
\text { backsliding }\end{array}$ & $\begin{array}{l}\text { Serious } \\
\text { backsliding }\end{array}$ & Early stage & Early stage \\
\hline Economic Criteria & Backsliding & $\begin{array}{l}\text { Serious } \\
\text { backsliding }\end{array}$ & Well advanced & Well advanced \\
\hline Competitiveness & Some & Some & Good & Good \\
\hline $\begin{array}{l}\text { Justice, Freedom } \\
\text { and Security }\end{array}$ & Good & Some & Moderately & Moderately \\
\hline
\end{tabular}

Source Own compilation based on European Commission reports (2018, 2019) 
of the EU-Turkey Association Council, and other high level dialogues in mid-2019 (Council of the EU, 2019c).

\subsection{CONCLUSION ANd OUTLOOK}

The EU's policy toward Turkey's membership has been, more so than in other cases, consistently ambivalent. Turkey's membership prospects were vague from the start and less credible than those of other accession candidates. In general, the conditionality effect is strongest when accession negotiations are about to be opened (as occurred with Turkey in the early 2000s) and when the EU is able to provide attractive incentives, such as visa liberalization throughout the long years of pre-accession. The debate over both the transformative power of the EU and Turkey's political commitment to transformation in terms of democratization, rule of law, human rights, and the pooling and transfer of sovereignty is ongoing (see Börzel, 2012, 2016; Noutcheva \& Aydın-Düzgit, 2012; Börzel \& Schimmelfennig, 2017; Schimmelfennig et al., 2003).

Some analysts argue that the EU was too hesitant and too internally divided to incentivize strong reform politics along these lines both before and during the critical years of the Erdoğan government (from 2013 onward) (Seufert \& Fischer, 2018: 278) - that the EU missed a big opportunity to contribute to the transformation of Turkey. Other analysts assume that the EU's leverage and influence were always significantly constrained by the politics and interests of Turkey's domestic actors. Thus, enlargement was at times a vehicle for Erdoğan to advance the dominance of his party and the political mission of conservativeauthoritarian rule in Turkey but not a vehicle for transformation on the EU's terms (Dağı, 2006). While the relationship between Brussels and Ankara was less asymmetric than in other cases of membership negotiations, because of Turkey's size and geostrategic importance, this did not translate into a relationship in which both parties saw eye to eye. Turkish governments have consistently complained of being treated as an underdog by the EU. And the EU is quite aware of the fact that its enlargement doctrine always works to its own advantage in terms of power. It also realizes that this is not the case when operating under transactional rules, as was the case with the so-called refugee 'deal'.

The ambivalences that characterized the opening of negotiations recur today in the question over suspending or even ending negotiations. Despite the massive deterioration in relations between Brussels and 
Ankara, the EU shies away from breaking up membership talks. For now, the EU wants to sustain the framework of the negotiations in order to keep open this channel for dialogue. Whenever there is a chance to restart the process, or at least provide impulses for a political process, the EU wants to secure the option to return to the negotiation table and use the accession framework. Even before the peak of the refugee crisis in 2015 and the deterioration of relations in mid-2016, there were plausible arguments to replace the enlargement framework with a more symmetric relationship as with other European countries, such as Norway, or the United Kingdom after Brexit. Alternatively, the accession framework could at least be accompanied by intensified political and security relations (high level dialogues, Turkey's integration into Permanent Structured Cooperation), the deepening and modernization of the $\mathrm{CU}$, and more liberal arrangements for free movement of people (see for similar argumentation, Soler i Lecha, 2019; Lippert, 2019b; Hakura, 2018).

Today, Turkey's accession process is almost a dead case. Interestingly, the updated enlargement strategy from spring 2020 refers explicitly to the 'credible EU perspective for the Western Balkans', leaving Turkey out of the enlargement picture (European Commission, 2020). However, the EU might be interested in more than a transactional relationship with Ankara that merely centers on controlling migration, fighting terrorism, and expanding trade. In contrast to some member states, the Commission and also parts of the European Parliament hold on to the transformative power of the accession process and membership perspective. Therefore, the ambivalence of the EU's approach to Turkey and its accession process is likely to continue.

\section{REFERENCES}

Alpan, B. (2021). Europeanization and Turkey's EU accession: Three domains, four periods. Chapter 5 , in this volume.

Barkey, H. J., \& Le Gloannec, A. (2005). The strategic implications of Turkey's integration in the European Union. In S. Fröhlich \& E. Brimmer (Eds.), The Strategic implications of European Union enlargement (pp. 127-150). Washington: Center for Transatlantic Relations.

Birkelbach, W. (1962). Bericht im Namen des Politischen Ausschusses über die politischen und institutionellen Aspekte des Beitritts zur Gemeinschaft oder 
der Assoziierung mit ihr. Europäisches Parlament, Sitzungsdokumente 1961/62. Dokument 122.

Börzel, T. (2012). Europeanization meets Turkey: A case sui generis? In Y. Özer \& Ç. Nas (Eds.), Turkey and the EU: Processes of Europeanisation (pp. 9-23). Aldershot: Ashgate.

Börzel, T. (2016). Building member states: How the EU promotes political change in its new members, accession candidates, and Eastern neighbors. Geopolitics, History, and International Relations, 8(1), 76-112.

Börzel, T., \& Schimmelfennig, F. (2017). Coming together or drifting apart? The EU's political integration capacity in Eastern Europe. Journal of European Public Policy, 24(2), 278-296.

Börzel, T. A., Dimitrova, A., \& Schimmelfennig, F. (2017). European Union enlargement and integration capacity: Concepts, findings, and policy implications. Journal of European Public Policy, 24(2), 157-176.

Bürgin, A. (2021). The European Commission's role in EU-Turkey relations. Chapter 9 , in this volume.

Carnegie Europe. (2018). Audio. 'Toward a renewed EU-Turkey Customs Union' Event. https://carnegieeurope.eu/2018/01/23/toward-renewed-eu-turkeycustoms-union-event-5796. Accessed 31 Jul 2020.

Ceylanoğlu, S. (2004). Europäische Wirtschaftsgemeinschaft, Griechenland und die Türkei: Die Assoziationsabkommen im Vergleich (1959-1963). Baden-Baden: Nomos.

Copsey, N., \& Haughton, T. (Eds.). (2012-2014). The JCMS annual review of the European Union. Issues 2012-2014. New Jersey: Wiley-Blackwell.

Council of the European Union. (2005). Enlargement: Turkey Declaration by the European Community and its member states. 12541/05 (Presse 243). Brussels, 21 September.

Council of the European Union. (2006a). Salzburg EU/Western Balkans joint press statement. 7283/06 (Presse 77). Brussels, 11 March.

Council of the European Union. (2006b). 2770th Council meeting, General Affairs and External Relations. Press release. 16289/06 (Presse 352). Brussels, 11 December.

Council of the European Union. (2014). 3362nd Council meeting, General Affairs. Press release. 16936/14 (Presse 652). Brussels, 16 December.

Council of the European Union. (2018). Enlargement and stabilisation and association process, council conclusions. 10555/18. Brussels, 26 June.

Council of the European Union. (2019a). Council conclusions on enlargement and stabilisation and association process. Press release. 18 June. https://www. consilium.europa.eu/en/press/press-releases/2019/06/18/council-conclu sions-on-enlargement-and-stabilisation-and-association-process/. Accessed 27 Nov 2020.

Council of the European Union. (2019b). Press statement following the 54th meeting of the Association Council between the European Union and Turkey in 
Brussels. Press release. https://www.consilium.europa.eu/en/press/press-rel eases $/ 2019 / 03 / 15 /$ press-statement-following-the-54th-meeting-of-the-ass ociation-council-between-the-european-union-and-turkey-brussels-15-march2019. Accessed 29 Nov 2020.

Council of the European Union. (2019c). Turkish drilling activities in the Eastern Mediterranean: Council adopts conclusions. Press release. 15 July. https://www.consilium.europa.eu/en/press/press-releases/2019/07/15/ turkish-drilling-activities-in-the-eastern-mediterranean-council-adopts-conclu sions/. Accessed 30 Jun 2020.

Dağı, İ. D. (2006). The Justice and Development Party: Identity, politics, and discourse of human rights in the search for security and legitimacy. In M. H. Yavuz (Ed.), The emergence of a new Turkey: Islam, democracy, and the AK Party (pp. 88-206). Salt Lake City: The University of Utah Press.

Dalay, G. (2018). Turkey-EU relations: Dysfunctional framework, status anxiety. Brookings Institution. https://www.brookings.edu/opinions/turkey-eu-relati ons-dysfunctional-framework-status-anxiety/. Accessed 30 Jun 2020.

Delegation of the European Union to Turkey. (2020): Accession negotiations. https://www.avrupa.info.tr/en/accession-negotiations-720. Accessed 27 Nov 2020.

Dokos, T., Tocci, N., Palm, A., \& Kasapoğlu, C. (2018). Greek-Turkish relations and the Cyprus dispute: Impact on Turkey-EU scenarios. FEUTURE Online Paper No. 27. December. https://feuture.uni-koeln.de/sites/feuture/user_u pload/Online_Paper_No_27.pdf. Accessed 27 Nov 2020.

Dürkop, C. (2018). Gesellschaftliche Europäisierung in der Türkei und Bild der EU. In B. Neuss \& A. Nötzold (Eds.), Türkei: Schlüsselakteur für die EU? (pp. 17-38). Baden-Baden: Nomos.

EEC-Turkey Association Agreement. (1963). Agreement establishing an association between the European Economic Community and Turkey. Official Journal of the European Communities, L 361/29-43, 31.12.1977.

European Commission. (1989). Commission opinion on Turkey's request for accession to the Community. SEC(89) 2290 final/2. Brussels, 20 December.

European Commission. (2005). Negotiating framework. Luxembourg, 3 October. https://ec.europa.eu/neighbourhood-enlargement/sites/near/ files/pdf/turkey/st20002_05_tr_framedoc_en.pdf. Accessed 31 Jul 2020.

European Commission. (2018). Turkey 2018 report. SWD(2018) 153 final. Strasbourg, 17 April.

European Commission. (2019). Turkey 2019 report. SWD(2019) 220 final. Brussels, 29 May.

European Commission. (2020). Enhancing the accession process- A credible EU perspective for the Western Balkans. COM(2020) 57 final. Brussels, 5 February. 
European Council. (1993). European Council in Copenhagen (21 and 22 June 1993)-Conclusions of the presidency. SN 180/1/93 REV 1. https://www.con silium.europa.eu/media/21225/72921.pdf. Accessed 29 Nov 2020.

European Council. (1999). Helsinki European Council (10 and 11 December 1997)—Presidency conclusions. https://www.consilium.europa.eu/media/ 21046/helsinki-european-council-presidency-conclusions.pdf. Accessed 29 Nov 2020.

European Council. (2004). Brussels European Council (16 and 17 December 2004)—Presidency conclusions. 16238/04. Brussels, 17 December.

European Council. (2007). Brussels European Council (14 and 15 December 2006) - Presidency conclusions. 16879/06. Brussels, 12 February.

European Council. (2015). Meeting of the EU heads of state or government with Turkey. 29 November 2015. https://www.consilium.europa.eu/en/mee tings/international-summit/2015/11/29/. Accessed 31 Jul 2020.

European Council. (2016). EU-Turkey statement, 18 March 2016. Press release. https://www.consilium.europa.eu/en/press/press-releases/2016/03/18/ eu-turkey-statement/. Accessed 27 Nov 2020.

European Parliament. (2017). European Parliament resolution of 6 July 2017 on the 2016 Commission report on Turkey (2016/2308(INI)). P8_TA(2017)0306. Strasbourg, 6 July.

European Parliament. (2019). European Parliament resolution of 13 March 2019 on the 2018 Commission report on Turkey (2018/2150(INI)). P8_TA(2019)0200. Strasbourg, 13 March.

Fraser, C. (Ed.). (2004). The future of Europe: Integration and enlargement. London and New York: Routledge.

Gavenda M. (2017). Austria. FEUTURE EU 28 country report, April. https:// www.feuture.uni-koeln.de/sites/feuture/pdf/Austria_28_Country_Report. pdf. Accessed 29 Nov 2020.

Goff-Taylor, M. (2017). The shifting drivers of the AKP's EU policy. Wilson Center. https://www.wilsoncenter.org/sites/default/files/media/doc uments/publication/shifting_drivers_of_akps_eu_policy.pdf. Accessed 30 Jun 2020.

Hakura, F. (2018). EU-Turkey Customs Union: Prospects for modernization and lessons for Brexit. Chatham House Briefing, December. https://www.cha thamhouse.org/sites/default/files/publications/research/2018-12-12-eu-tur key-customs-union-hakura.pdf. Accessed 31 Jul 2020.

Hillion, C. (2010). The creeping nationalisation of the EU enlargement policy. Report No. 6. November. Stockholm: Swedish Institute for European Policy Studies. 
Hoffman, M., \& Werz, M. (2019). The effects of a suspension of Turkey's EU accession process. Stiftung Mercator. https://www.stiftung-mercator.de/ media/downloads/3_Publikationen/2019/2019_09/The_effects_of_a_sus pension_of_turkey_s_EU_accession_process_study.pdf. Accessed 31 Jul 2020.

Hughes, K. (2004). Turkey and the European Union: Just another enlargement? Exploring the implications of Turkish accession (A Friends of Europe Working Paper). June.

İçener, E., Phinnemore, D., \& Papadimitriou, D. (2010). Continuity and change in the European Union's approach to enlargement: Turkey and Central and Eastern Europe compared. Southeast European and Black Sea Studies, 10(2), 207-223.

Juncker, J. (2016). Speech at the annual general meeting of the Hellenic federation of enterprises. Athens. http://europa.eu/rapid/press-release_SPEECH16-2293_en.htm. Accessed 30 Jun 2020.

Kaeding, M., \& Schenuit, F. (2021). The European Parliament's perspective on EU-Turkey relations. Chapter 10, in this volume.

Karadag, R. (2017). Die Rolle der Türkei in der Region: (Un-)Ordnungsgarant in einem neuen Nahen Osten. Aus Politik und Zeitgeschichte, 67(9-10), 4246.

Kramer, H., \& Reinkowski, M. (2008). Die Türkei und Europa: Eine wechselhafte Beziehungsgeschichte. Stuttgart: Kohlhammer.

Leggewie, C. (2004). Die Türkei und Europa: Die Positionen. Frankfurt a. M.: Suhrkamp.

Leiße, O., \& Tryk, M. (2004). Der Dauerkandidat: Die Europäisierung der Türkei unter der AKP. Integration, 37(1), 45-64.

Lippert, B. (1999). Erweiterung und Agenda 2000. In W. Weidenfeld \& W. Wessels (Eds.), Jabrbuch der europäischen Integration 1998/1999 (pp. 37-48). Baden-Baden: Nomos.

Lippert, B. (2000). Erweiterungspolitik der Europäischen Union 1999/2000. In W. Weidenfeld \& W. Wessels (Eds.), Jabrbuch der europäischen Integration 1999/2000 (pp. 35-46). Baden-Baden: Nomos.

Lippert, B. (2005a). Die Türkei als Sonderfall und Wendepunkt der klassischen EU-Erweiterungspolitik. Integration, 28(2), 119-135.

Lippert, B. (2005b). Erweiterungspolitik der Europäischen Union 2005. In W. Weidenfeld \& W. Wessels (Eds.), Jabrbuch der europäischen Integration 2005 (pp. 425-434). Baden-Baden: Nomos.

Lippert, B. (2006). Die Erweiterungspolitik der Europäischen Union 2006. In W. Weidenfeld \& W. Wessels (Eds.), Jabrbuch der europäischen Integration 2006 (pp. 429-440). Baden-Baden: Nomos.

Lippert, B. (2011). The big easy? Growth, differentiation and dynamics of EUenlargement policy. In U. Diedrichs, A. Faber, F. Tekin, \& G. Umbach (Eds.), Europe reloaded: Differentiation or fusion? (pp. 238-268). Baden-Baden: Nomos. 
Lippert, B. (2015). Die Erweiterungspolitik der Europäischen Union. In W. Weidenfeld \& W. Wessels (Eds.), Jahrbuch der europäischen Integration 2015 (pp. 521-528). Baden-Baden: Nomos.

Lippert, B. (2017). Die Erweiterungspolitik der Europäischen Union. In W. Weidenfeld \& W. Wessels (Eds.), Jahrbuch der europäischen Integration 2017 (pp. 419-427). Baden-Baden: Nomos.

Lippert, B. (2018). Die Erweiterungspolitik der Europäischen Union 2018. In W. Weidenfeld \& W. Wessels (Eds.), Jabrbuch der europäischen Integration 2018 (pp. 367-377). Baden-Baden: Nomos.

Lippert, B. (2019a). Die Erweiterungsgeschichte der Europäischen Union: Verlauf, Dynamik und Perspektiven. In P. Becker \& B. Lippert (Eds.), Handbuch Europäische Union (pp. 1-29). Wiesbaden: Springer Fachmedien.

Lippert, B. (2019b). Die EU und ihre Nachbarschaftsbeziehungen: Etablierte Assoziierungsmodelle und neue Grundformen. Integration, 42(2), 83-97.

Michel, T., \& Seufert, G. (2016). Turkey's failed pursuit of hegemony in the Middle East: Three periods of Turkey's 'independent' foreign policy. In M. Johannsen, B. Schoch, M. Mutschler, C. Hauswedell, \& J. Hippler (Eds.), Peace report (pp. 73-88). Zurich: LIT Verlag.

Morillas, P., Sökmen, M., \& Ünver, A. (2018). Die Beziehungen zwischen der EU und der Türkei in einem stürmischen globalen Umfeld. Integration, $41(1), 5-25$.

Noutcheva, G., \& Aydın-Düzgit, S. (2012). Lost in Europeanisation. The Western Balkans and Turkey. West European Politics, 35(1), 59-78.

Özbey, E. E., Hauge H., Rumelili, B., \& Eralp, A. (2019). Identity representation in the narratives on the EU-Turkey relations (FEUTURE Online Paper No. 32). http://www.feuture.uni-koeln.de/sites/monteus/ user_upload/FEUTURE_Online_Paper_No._32.pdf. Accessed 30 Jun 2020.

Özerdem, A., \& Whiting, M. (Eds.). (2019). The Routledge handbook of Turkish politics. London: Routledge.

Pierini, M. (2019). Options for the EU-Turkey relationship. Carnegie Europe. https://carnegieeurope.eu/2019/05/03/options-for-eu-turkey-rel ationship-pub-79061. Accessed 10 Aug 2020.

Powell, C. (2015). The long road to Europe: Spain and the European Community, 1957-1986. Real Instituto Elcano. http://www.realinstitutoelcano.org/wps/ wcm/connect/6a64870048b28234b015fb735801e64l/DT9-2015-PowellLong-Road-Europe-Spain-Europea-Community-1957-1986.pdf?MOD=AJP ERESandCACHEID $=6 \mathrm{a} 64870048 \mathrm{~b} 28234 \mathrm{~b} 015 \mathrm{fb} 735801 \mathrm{e} 641$. Accessed 10 Aug 2020.

Radaelli, C. (2003). The Europeanisation of public policy. In K. Featherstone \& C. Radaelli (Eds.), The politics of Europeanization (pp. 27-56). Oxford: Oxford University Press.

Rehn, O. (2006). Europe's next frontiers. Baden-Baden: Nomos. 
Schimmelfennig, F. (2008). EU political accession conditionality after the 2004 enlargement: Consistency and effectiveness. Journal of European Public Policy, 15(6), 918-937.

Schimmelfennig, F. (2018). Beyond enlargement: Conceptualizing the study of the European Neighbourhood Policy. In T. Schumacher, A. Marchetti, \& T. Demmelhuber (Eds.), The Routledge handbook on the European neighbourhood (pp. 17-27). London: Routledge.

Schimmelfennig, F., Engert, St, \& Knoble, H. (2003). Costs, commitment and compliance: The impact of EU democratic conditionality on Latvia, Slovakia and Turkey. Journal of Common Market Studies, 41(3), 495-518.

Seufert, G. (2011). Türkei. In W. Weidenfeld \& W. Wessels (Eds.), Jabrbuch der europäischen Integration 2011 (pp. 521-526). Baden-Baden: Nomos.

Seufert, G. (Ed.). (2018a). Die Kurden im Irak und Syrien nach dem Ende der Territorialherrschaft des 'Islamischen Staates': Die Grenzen kurdischer Politik. SWP-Studie No 11. https://www.swp-berlin.org/fileadmin/con tents/products/studien/2018S11_srt.pdf. Accessed 27 Nov 2020.

Seufert, G. (2018b). Turkey's shift to executive presidentialism: How to save EU-Turkish relations. Südosteuropa-Mitteilungen, 3(2018), 6-19.

Seufert, G., \& Fischer, S. (2018). Transformation misslungen: Die EU. Russland und die Türkei. Osteuropa, 68(10-12), 271-290.

Seufert, G., \& Kubaseck, C. (2006). Die Türkei: Politik, Geschichte, Kultur. München: C.H. Beck.

Soler i Lecha, E. (2019). EU-Turkey relations: Mapping landmines and exploring alternative pathways (FEPS Policy Paper). https://www.feps-europe.eu/att achments/publications/feps_eu_turkey_relations_soler.pdf. Accessed 27 Nov 2020.

Talbot, V. (Ed.). (2018). Turkey: Towards a Eurasian shift. Milan: ISPI.

Tekin, F. (2017). Quadratur des Kreises? Hintergründe der EU-TürkeiBeziehungen. Aus Politik und Zeitgeschichte, 67(9-10), 36-41.

Tekin, F. (2021). Differentiated Integration: An alternative conceptualization of EU-Turkey relations. Chapter 7 , in this volume.

Tocci, N. (2014, November). Turkey and the European Union: A journey in the unknown (Brookings Institution, Turkey Project Policy Paper No. 5). https://www.brookings.edu/wp-content/uploads/2016/06/ Turkey-and-the-European-Union.pdf. Accessed 10 Aug 2020.

Torun, Z. (2021). From convergence to divergence: The compatibility of Turkish and EU foreign policy. Chapter 13, in this volume.

Turhan, E., \& Reiners, W. (2021). Unpacking the new complexities of EUTurkey relations: Merging theories, institutions, and policies. Chapter 1 , in this volume. 
Turhan, E., \& Wessels, W. (2021). The European Council as a key driver of EU-Turkey relations: Central functions, internal dynamics and evolving preferences. Chapter 8 , in this volume.

Weidenfeld, W., \& Wessels, W. (Eds.). (2005-2019). Jahrbuch der europäischen Integration. Issues 2005-2019. Baden-Baden: Nomos.

White, D., \& Herzog, M. (2018). Examining state capacity in the context of electoral authoritarianism, regime formation and consolidation in Russia and Turkey. Southeast European and Black Sea Studies, 16(4), 551-569.

YouGov. (2016). Eurotrack survey results. https://d25d2506sfb94s.cloudfront. net/cumulus_uploads/document/q2g2dcxcv9/Eurotrack_July_CountriesP ositiveNeg_Website.pdf. Accessed 30 Jun 2020.

Barbara Lippert is the director of research and member of the executive board of the German Institute for International and Security Affairs (Stiftung Wissenschaft und Politik, SWP) in Berlin. Before, she was the deputy director of the Institute for European Politics (IEP) in Bonn and Berlin from 1992 to 2009 and lecturer at various universities in Cologne and Berlin. Her research interests include the political system of the EU, EU enlargement policy, European Neighbourhood Policy, and Germany's European policy. Lippert studied political science, modern history, Eastern European history, and Slavic philology at Bonn University and Free University Berlin. She received her Ph.D. from the University of Bonn.

Open Access This chapter is licensed under the terms of the Creative Commons Attribution 4.0 International License (http://creativecommons.org/licenses/ by $/ 4.0 /)$, which permits use, sharing, adaptation, distribution and reproduction in any medium or format, as long as you give appropriate credit to the original author(s) and the source, provide a link to the Creative Commons license and indicate if changes were made.

The images or other third party material in this chapter are included in the chapter's Creative Commons license, unless indicated otherwise in a credit line to the material. If material is not included in the chapter's Creative Commons license and your intended use is not permitted by statutory regulation or exceeds the permitted use, you will need to obtain permission directly from the copyright holder.

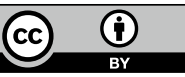

